\title{
CHRISTOPHER Populism, Cosmopolitanism, MECKSTROTH or Democratic Realism?
}

\begin{abstract}
This article argues that populism, cosmopolitanism, and calls for global justice should be understood not as theoretical positions but as appeals to different segments of democratic electorates with the aim of assembling winning political coalitions. This view is called democratic realism: it considers political competition in democracies from a perspective that is realist in the sense that it focuses not first on the content of competing political claims but on the relationships among different components of the coalitions they work to mobilise in the pursuit of power. It is argued that Laclau's populist theory offers a sort of realist critique of other populists, but that his view neglects the crucial dynamics of political coalition-building. When the relation of populism to global justice is rethought from this democratic realist angle, one can better understand the sorts of challenges each faces, and also where and how they come into conflict.
\end{abstract}

Keywords: populism; global justice; cosmopolitanism; realism; democracy.

\section{Introduction}

In recent years, a great deal of discussion both in the academy and in contemporary politics has focused on conflicts between populist demands for self-determination, on the one hand, and the authority of cosmopolitan principles or transnational institutions, on the other. Although some populisms, usually on the political left, aim to reconcile popular sovereignty with internationalism, many more (including others on the left) insist on a deep tension or outright incompatibility. In this article, I am not interested in sorting out whether this conflict of principles or political styles is indeed necessary. Instead, I mean to challenge the terms of this debate by introducing a third position which I take to compete with both populism and cosmopolitanism, across the range of ways in which each is commonly understood. ${ }^{1}$ I call this view democratic realism, and although I cannot attempt a comprehensive defence of it here, I will show where it differs from the other two and how it offers a distinctive perspective on some of the issues at stake in debates among cosmopolitans and populists.

Democratic realism is 'realist' in that it asks us to consider something other than only the justice or morality of competing political claims. Recent literature

1 For diverse definitions of populism see Müeller (2016), Mudde and Rovira Kaltwasser (2017), Kazin (2017), Mansbridge and Macedo (2019), and the essays collected in Rovira Kaltwasser et al. (eds) (2017). My claims are framed broadly enough to sidestep most of these debates. 
has much debated the meaning of varieties of 'realism.'2 The way I will use the term, it means that in evaluating a political position, what we want to know first of all is who that position would help to put in power, and on what terms. This view begins from the assumption that politics involves collective decisions concerning the use (or potential use) of coercion, and so every political programme will create and sustain distinctive relationships of power. Rallying around a certain programme allows some persons to put themselves, together, in a position to shape the outcome of collective decisions, and this creates new power relations, both among those persons themselves (the members of a governing coalition) and also between them and other persons who, although overruled in the decisions, are also impacted by the results.

Democratic realism is 'democratic,' then, in that it focuses on how this general political dynamic plays out in modern democracies, in which the ability of rulers to sustain their position of power depends on iterated success in competitive mass elections. In a complex modern society, at least, governing typically requires holding together a political coalition that includes persons across some range of characteristics within a large and diverse electorate. For this reason, it makes sense to focus not only on political relationships of 'rulers' to 'ruled,' but also on relations of power inside ruling coalitions. Democratic realism, then, asks us to evaluate competing political positions by considering not the merits of their claims, but the quality of the political relationships of power those claims help to reproduce. Because there are many power relations in complex societies other than these expressly political ones, moreover, it is important to consider the political relationships against the background of other, social, relations as well.

Democratic realism is open to a wide range of evaluative standards for judging these different relations of power, both normative and pragmatic. So some democratic realists might prioritise a certain notion of freedom, others equality, still others security or social peace, but they would all agree on applying their respective standards, not to the content of political claims, but instead to the power relations that certain political programmes help to sustain, against the background of other relations of social power. Bernard Williams famously argued for a sort of realism that, following Hobbes, considers 'the first political question' to concern the maintenance of social and political order (Williams, 2005: 3). Whilst accepting this point, democratic realism recognises that conflicts over power continue even inside stable political orders,

2 See inter alia Galston (2010); Geuss (2008); Hall (2015); Hall and Sleat (2017); McQueen (2017); Prinz and Rossi (2017); Rossi (2019); Rossi and Sleat (2014); Sagar (2014); Sagar and Sabl (eds) (2018); Sangiovani (2008); Sleat (2013); Sleat (ed) (2018); Waldron (2013); Williams (2005). 
and so it goes on to ask a further question about the conditions under which collective political decisions are made in competitive modern democracies. ${ }^{3}$ In societies that have managed to answer Williams' first question, then, I want to turn attention to what I accordingly call the second political question: which potentially winning political coalition might any given programme help put into a position to govern?

This contrasts sharply with much of the theoretical literature on populism, which focuses heavily on what populists say, in order to defend or criticise either their principles or their style of political rhetoric (e.g., Canovan, 1999; Mansbridge and Macedo, 2019), while other works go on to consider also what populists $d o$, once in power, in terms of particular policies or impacts on state institutions (Mudde, 2013; Mueller 2016). Some studies have used ethnographic methods to capture a sense of organization and political culture inside populist movements themselves (Gerbaudo, 2017). A democratic realist perspective on populism shares some concerns with this last direction, but it distances itself from populists' own self-description of their practices to focus squarely on the question of what sort of political coalition they would put in power. Of course what that coalition goes on to do also matters, but understanding the political stakes of what it will do requires one to consider that policies matter not only because of their content but also because of the way they work either to challenge or to shore up the positions of those in power. In other words, what matters is not only what is done but also who is doing it to whom. This is the question that democratic realism insists we must never lose from our sight.

This approach also contrasts with much of the literatures on cosmopolitanism and global justice, focused on the normative justification of principles. ${ }^{4}$ Critics object that cosmopolitan or universalist ideals are regularly employed to cloak the assertion of imperialist or quasi-imperialist forms of geopolitical power (Cohen, 2006). But rather than launch another salvo in the long-running debate over a general scepticism with regard to normative principles in politics, democratic realism chooses to focus attention on the stakes of democratic contests for power among cosmopolitans and their opponents. It asks political questions about the relations of power involved in efforts to advance one or the other sort of programme, and suggests that this is the terrain on which these programmes should be judged. This is not because either cosmopolitan or antiimperialist arguments on behalf of persons across state borders are obviously without moral weight, but because they are of a different sort than arguments over political relationships among those citizens of democracies potentially in

3 I don't mean to downplay the significance of Williams' first question, which remains an important and ever-present limiting condition even in ostensibly stable polities, but that is not the focus of this piece.

4 See inter alia Caney (2005); Pogge (2002); and Risse (2012). 
a position to exert control over their own governments and thereby actually to determine the policies that will affect both themselves and others on distant shores. Democratic realism is realist in prioritising neither moral appeals nor charges of moral hypocrisy, but arguments over the quality of power relations among those potentially in a position to change things. Perhaps this is not the only sort of argument of value in politics, but surely there is value in showing clearly that more familiar moralist and moral-sceptical alternatives do not exhaust the range of considerations we might choose to take into account.

Although this view is realist, it is not therefore anti-normative. It simply insists that evaluative standards, including normative ones, should be applied not to the content of competing political claims, but instead to the relationships of political power that the circulation of those claims helps to create and reproduce. It resolutely refuses to take political actors' rhetoric or selfdescriptions at face value, and instead invites us to consider the work they do. So for instance, when populists claim to speak for 'the people' versus some 'elite,' a democratic realist does not accept this as an adequate description of the power relations inside a populist movement or between that movement and others in society. But neither is the democratic realist scandalised that such claims may be used instrumentally in the pursuit of power. This is simply true of all political programmes, ideologies, and identities. A democratic realist is equally suspicious when cosmopolitans or liberals purport to speak for the universal interests of all humankind; this too involves a sort of rhetorical positioning that may function to reinforce a sense of shared identity among those who look upon themselves as the party of reason and morality waging a righteous battle against the forces of ignorance and egoism. A democratic realist does not accept any of these self-descriptions on face, but asks in every case what political work they do, how they function in a democratic competition for power by appealing to discrete segments of electorates with the aim of putting together coalitions strong enough to win and to impose their will over the objections of other fellow citizens.

When the conflict between populists and cosmopolitans is reinterpreted this way, not as a clash of ideals but as competing attempts to assemble winning democratic coalitions, then its stakes appear in a very different light. It might be that new compromises could be found, or else that one or the other side might better advance its cause by seeking to build different or broader alliances, perhaps by changing the form or register of some of its core claims. But whatever the result, the point would be that the debate would play out on different ground, considering how different sorts of appeals might target or help to redefine the perceived interests or identities of different electoral blocs, and the shape of the power relations likely to result. 
This article makes a prima facie case for this democratic realist view by showing how it advances current theoretical analyses of populism and its relation to cosmopolitanism and global justice. It proceeds in three parts. The first two engage the work of Ernesto Laclau, which offers perhaps the most theoretically sophisticated contemporary account of populism and one sometimes cited by populists themselves. ${ }^{5}$ Section one points out that Laclau's radically constructivist account, according to which 'the people' is an arbitrary rhetorical construct assembled by populists in the pursuit of power, actually provides a withering critique of every other, more familiar sort of populism that instead depends on the claim that some real 'people' exists and that its real and sovereign 'will' must be allowed to rule. The view I defend agrees with Laclau in this constructivism. But section two argues that Laclau's understanding of construction is itself naïve in presuming that political identities and collective actors can be constructed at will through rhetorical devices of identification and polarisation. What Laclau's account ignores is, first, the extra-linguistic social relationships that provide context including potential conflicts of interest among different electoral blocs, conflicts which always threaten to swamp appeals to rhetorical unity unless they can be acknowledged and negotiated. It also ignores, second, the political relationships internal to the collective decisionmaking process of any movement, which again are commonly irreducible to the movement's own rhetoric of mobilisation. These are relations among political agents, not only among the signifiers they might employ.

After highlighting the stakes of the core premises of democratic realism in this way, by showing how it improves on Laclau's particularly sophisticated version of populist theory, section three then goes on to consider how a democratic realist perspective might allow one to rethink the relations among populism, cosmopolitanism, and global justice from a new and potentially more enlightening angle. My conclusions are analytic, rather than directive. I do not argue either for or against populist or cosmopolitan programmes, for instance, but for an analytic perspective, itself neither populist nor cosmopolitan but democratic and realist, which offers a way of arguing for or against any particular programme in a given historical setting.

\section{Why Sovereignty is not Realist}

It is often suggested by populists that the authority of principles of cosmopolitanism or global justice, as well as that of trans- or supranational institutions that might enforce them, can only serve to limit the legitimate sovereignty of democratic peoples. ${ }^{6}$ This may be tied to a critique of

5 See, e.g., Errejón and Mouffe (2016).

6 See, e.g. Gourevitch (2019). For a contrasting view see Ingram (2017). 
constitutionalism or legalism, which are sometimes associated with liberalism as contrasted to democracy. In some of its most sophisticated versions, this critique allows defenders of the view to deny that their position relies essentially on potentially objectionable nationalist presuppositions. There are both theoretical and practical reasons why populisms and nationalisms often strongly overlap, but it is indeed possible for theorists coherently to defend a statist position that relies instead on anti-legalism, according to which although there may be no intrinsic reason to prefer national states, given the existence of state-level democratic institutions any international limitations on their arbitrary authority to determine their own laws and policies would result in a system in which unelected 'lawyers' or other unaccountable or less directly accountable institutional 'elites' could be said to have wrested control from the sovereign democratic people. To see the difference, consider how this position might allow one to defend for instance the sovereignty of the UK electorate against the European Court of Justice (although not so straightforwardly against either the European Parliament or the Council), without thereby committing oneself also to supporting national independence for any of the four nations commonly held to comprise the multinational United Kingdom.

A common response from critics of populism holds that, far from democracy and law or constitutionalism being in fundamental tension, the former can instead be said to depend necessarily on the latter, and perhaps also vice-versa (Brettschneider, 2007; Habermas, 1996; Urbinati, 2014). Although I think there is much to be said for this response, I am not convinced it is sufficient. As a historical point, this presupposes a specific and relatively modern view of democracy as liberal or representative democracy, neither of which compound terms would have made any sense at all before the end of the eighteenth century or the beginning of the nineteenth. Nor is it clear even today that this view is as generally accepted as its proponents suppose. To the contrary, many of the great episodes of democratic history in the nineteenth and certainly the twentieth centuries turned precisely on live and continued conflict over competing views of what something like democracy or popular sovereignty or self-determination would come to mean in an increasingly modern world - a world in which dynastic or other competing claims to sovereign authority no longer seemed able to hold (Frank, 2010; Rosanvallon, 1998). And although one may of course fairly emphasise the distinctions between movements such as socialism, Communism, Fascism, or National Socialism, on the one hand, and 'democracy,' on the other, it is also important not to lose sight of the way they were all part of the same historical debates over what were to be understood as the conditions of popular rule. Today the problem remains that populists, in particular, may simply not accept the equation of democracy and rights- 
based constitutionalism - consider for instance how Orbán has made 'illiberal democracy' into a rallying cry (2018) - which means this response will seem to them to beg the question.

So here I propose a different tack. I think not nearly enough attention has been focused on a central conflict among defenders of broadly populist positions. If what I will call the sovereigntist (or popular sovereigntist) interpretation is most straightforward, it is important to note that the widely-cited and sophisticated theory advanced by Ernesto Laclau competes very fundamentally with that view. Laclau (2005) argues that the 'people' is a politico-linguistic construct, an 'empty signifier' that must be given content by the arbitrary linking together of different 'demands' into an 'equivalential chain,' in order to construct identification with a collective subject defined in opposition to some 'antagonistic camp' whom it aspires to deny any share in power. What is important here is that this radically constructivist view rejects entirely the ontological status of any potentially sovereign 'people,' reducing that people to an instrumental, rhetorical construct, whilst also rejecting any criterial framework of legitimacy that would enable meaningful distinctions between rightful and unrightful authority. ${ }^{7}$ In other words, popular sovereigntists need to claim that the people actually has some real will that has a rightful claim to rule, whereas Laclau argues that the 'people' is only a rhetorical device that makes possible the organizing of a political subject potentially capable of seizing power, whether or not it has any right to. ${ }^{8}$ I think it is to Laclau's credit that he is up front about this, as comes through clearly in his critique of Rancière, whom he believes,

'identifies the possibility of politics too much... with the possibility of an emancipatory politics, without taking into account other alternatives - for example, that the uncounted might construct their uncountability in ways that are ideologically incompatible with what either Rancière or I would advocate politically (in a Fascist direction, for instance)' (Laclau, 2005: 246).

Of course, it is possible for a Laclauian constructivist to advocate for a populist position by using sovereignty language instrumentally, but what is not possible is that she should actually believe it. They know the people has no will that populist movements represent but is rather a creature of those movements'

7 He does sometimes use the word 'legitimate,' but always only from an instrumental point of view, to describe an aspiration to seize power, e.g.: the 'people' 'is a partial component which nevertheless aspires to be conceived of as the only legitimate totality' (Laclau, 2005: 81).

8 Although Laclau provides perhaps the most elaborate theoretical account of this sort of constructivism, the view that the 'people' is a rhetorical construct is common in the historical literature on populism; see notably Kazin (2017) and Morgan (1988), but contrast Goodwyn (1976). For a theoretical overview see Canovan (2005). 
own invention, in the service of political advancement and the pursuit of power. Popular sovereigntists, on the other hand, ostensibly need to think the people actually has a will and the point is supposed to be not seizing power for its own sake but only toward the end of giving effect to the people's will, about whose content leaders could at any point turn out to be mistaken. Indeed, I am inclined to suspect that this confusion is not of merely theoretical interest, but that the easy slippage between one claim ('I speak for what the real people really want') and another ('I speak for whomever will rally with me so that we can together seize control and call our voice "the people's"') is a common and important element in the history of populism and related movements.

So, my first main point is that Laclau's constructivist populism is fundamentally at odds with sovereigntist populism, and therefore, in a way that I do not think has received the attention it deserves, the former offers one very powerful critique of the latter. This is not to endorse Laclau's overall view or where he ends up (as will become clear), but it is to point out that sovereigntists need to press their case not only against cosmopolitans or legalists but simultaneously against radical constructivists like Laclau. In fine, if it might well turn out that 'the people' is often a rhetorical construct invented by populist leaders to facilitate their own seizure of power, rather than a genuine reflection of some ontologically infallible popular will, then very many of the familiar objections raised by sovereigntists to cosmopolitanism or transnational legal institutions would appear to be built on sand. Or put another way, if the 'people' is no more real and pre-political than 'law' or 'rights' or 'constitutions' or any of the other things sovereigntists commonly attack as artificial, anti-political abstractions imposed by elites, then we would need some other sort of framework for thinking through which of these sorts of principles it was better to build a political system around. One might go further to point out that 'sovereignty' has always been a legal concept - a name for a position inside a system of law - ever since Bodin coined the relevant sense of the term in the late sixteenth century. ${ }^{9}$ Essential to Bodin's view, moreover, was the characteristically iconoclastic Anti-Aristotelian premise that a city (or polis) is defined not by any sort of geographical proximity or natural unity but entirely by subjection to the same laws; a republic, which might contain several cities with different laws, consists in their unity under the same sovereignty (Bodin, 1576: B I, Ch.6). And so, what we really face here are choices among different principles through which one could choose to construct and structure political relations, not a simple decision between (alien, constraining) law and (self-legislating, emancipated) popular will. The issue of

9 Indeed, it was also a legal term before, though the sense was different. The pivotal discussion is in Bodin's Six livres de la république of 1576, Book I, chapter 8. On the historical construction of the notion of 'popular sovereignty' over the centuries, see Bourke and Skinner (eds) (2016). 
a tension between law and democracy does not disappear, but at least we can see clearly that it is no less of a problem for champions of popular sovereignty than for any other sort of democrat.

At this point two objections will be raised. First, it will be said that I have not 'proved' that the sovereign people is only a rhetorical fiction, but have simply followed Laclau on this. Second, it will be suggested that it does not matter if the sovereign people is a fiction, since such a fiction can still play a valuable role in normative arguments concerning the legitimacy of political authority. Both points are true, but I do not think they undercut the force of my argument. I do think the 'people' must be understood in a constructivist fashion, but I won't repeat here theoretical arguments I've made elsewhere for this view. ${ }^{10}$ Here I am only arguing against one sort of populist critique of cosmopolitanism, the sort that accuses trans-national legal institutions of intrinsically frustrating a true popular will. Surely the burden of proof here falls on those who would need to demonstrate the reality and normative priority of that putative will. They would need to show that some sort of domestic political system expresses a natural, pre-political sovereign will that was not already legally constituted, in order to see why one could not take complex international institutions particularly if they have been created by and ratified by domestic governments as alternate ways of pursuing the same democratic ends. That argument is hard to make, however, and especially so if one does not want to identify peoples, as David Miller (2007) does, with cultural nations. ${ }^{11} \mathrm{I}$ am simply pointing out that scepticism concerning the transparency of ideals such as law and human rights ought to be no less applicable to other idealisations like that of a united sovereign people.

It is also true that a legal fiction, such as the sovereign people, may have important and perfectly legitimate uses. Every legal system, including democratic political systems, is based upon such fictions, which play essential roles in establishing norms that both make the system work and bear on its legitimacy as a whole. But the point here is that because the sovereign people is a fiction a way of talking about politics that allows people to do politics in one way rather than another - it is never also a full and accurate description of the entirety of the political relationships that it helps to make possible. In the best case, some set of complex institutions in which certain party leaders exercise certain kinds of authority checked in some ways by elections and legal norms adds up to a system that is acceptable as not incompatible with an ideal of generalized selfrule. But if we focus entirely on the conceptual relations around the ideal, we

10 See Meckstroth (2015).

11 Cf. Miller (2020) for a defence of 'self-determination' that relies less directly on nation but still in the end favours cultural identity as a ground for membership. 
leave ourselves vulnerable to the criticisms of realists, including some populists, who may fairly charge that we neglect other real social and political relations no less important than the ideal ones. For example, two democratic majorities will be equally legitimate, on democratic principles, even if each is supported by a political coalition that favours the respective economic interests of different regions, industries, or people of particular educational backgrounds (so long, I would argue, as neither could be said to violate the equal freedoms of any particular set of citizens). But the two results, though both legitimate, are not the same, and the differences may be of the greatest political salience. They might include normative or practical reasons one would hope for one of the coalitions to win, or what sort of compromises or new ways of building alliances might be required in order to succeed in a given context. If democratic theorists insist on arguing exclusively about the normative ideals, all of this ground will be ceded to sceptics and populist critics, and one will remain perpetually vulnerable to the familiar charge that one's theory has lost its point of contact with political realities of the day.

\section{Constructivism and/or Realism}

Laclau's radical constructivism shows up nicely what one is expected naïvely to take for granted by other defences of populism. But Laclau's own populism is also deeply flawed, in another way that is equally revealing. Here I am not concerned with normative objections, for instance that his view ends up subordinating pluralism to unity in the final instance, despite his professed aim to the contrary, or that it eliminates critical standards of legitimacy (see McKean, 2016). This may be so, but I want to take an opposite tack. Rather than push back against Laclau for not being normative enough, what if we instead followed and radicalised what I have portrayed as the demystifying realism of his critique of the idealisations of popular sovereigntists? We can agree that political identities and collective subjects are constructed. But how realistic is Laclau's account of how that construction works?

On this score, I find at least three, cumulatively fatal, flaws in his view. The first is that it collapses political analysis too neatly into linguistics (and poststructuralist psychoanalysis). Because Laclau reads all political relations in terms borrowed from the analysis of language, his view risks mistaking populist rhetoric for the whole of populist politics (or if one prefers, reading all political and social relations as if they were relations among symbols). This is a problem because the content of political rhetoric is never a sure guide to the nature of the political relationships it works to reproduce; indeed, rhetoric and ideology are often used expressly to obscure or mystify some aspects of those relations. Second, Laclau's view of linguistic construction is implausibly voluntaristic, 
and this carries over into an overly voluntaristic approach to the construction of political identities. And third, because Laclau focuses on the logic of symbols, he fails to consider the significance of the disparate sizes of the social groups symbolic appeals are meant to target. This leaves him entirely unequipped to identify which potential political coalitions, in a given society, might be in a position to win.

Consider the second point first. Laclau is right to reject the social determinism and fixation on 'class' in traditional Marxism, but his reaction somewhat overshoots the mark. ${ }^{12}$ I accept the core point that politically relevant social categories including 'class' and 'people' are themselves politically constructed, that they are in the first instance names used to sustain certain political relationships rather than objective descriptions of social ontology. ${ }^{13}$ But even if no unique interests, identities or social antagonisms are objectively determined prior to a collective political act of naming, it is still the case that as soon as one does name them in one way rather than another this creates particular oppositions that cannot then be ignored. For example, if one chose to attack elites in the name of a British people personified by English working men in post-industrial cities who blame immigration for local economic decline, then this would make it more challenging to rally alongside them for instance recent immigrant workers in thriving metropolitan areas, as well as progressive cosmopolitans - either of whom might well have their own quarrels with many of the same 'elites.' This is not to suggest that such groups are destined to be at odds, but to the contrary that the way one chooses to mobilise each will have consequences for one's ability also to hold together a common project with the others. The point is not to blame one or the other of the blocs, but to recognise that grievances are not all perfectly fungible; and that, to the contrary, the choice to polarize around one particular cleavage rather than another is commonly a strategic choice meant to divide an opposing coalition or to force it onto electorally weaker ground.

Laclau does not offer a way of thinking about these sorts of choices. Although he insists that 'hegemonic' identities must be constructed by linking the demands of diverse groups (so in this sense not by pure 'arbitrary fiat'), he implies that it follows from the radical malleability of group interest and identity that one may choose to link any number of groups together in an endless 'equivalential chain.' He ignores the need for hard choices about who to include at the price of excluding others, and also how the nonidentical interests of different blocs, once defined, inevitably raise questions of how to hold together a working

12 The preoccupation with this distancing from Marxism is more emphatic in Laclau and Mouffe (2001).

13 Laclau rightly cites the pathbreaking essay on 'Languages of Class' by Gareth Stedman Jones (1983). 
coalition without some blocs feeling subordinated to others. The presumption appears to be that this hard political work is unimportant if one succeeds in the symbolic struggle to unify all sides around a 'hegemonic' identity. To be sure, Laclau stresses that unification can go too far - he wants a unity compatible with pluralism, and warns against authoritarian identifications that are not. But his solution - don't unify too much - ignores completely the specific, qualitative choices, trade-offs, and balancing acts that are the life's blood of coalition politics.

This is then immediately compounded when one considers that relevant relations exist not only among terms in language, but also among actual persons in social space. So, not only may concepts of interest or identity conflict, but the actual person picked out by a certain concept - say that English working man in the declining industrial city - also stands in a number of real social and political relationships to other persons, relations which are not reducible to language. ${ }^{14}$ Some of these are economic, some may come down to geographical proximity, others may have to do with shared histories or education or experiences. Laclau is surely right that none of these sorts of relationships are themselves sufficient to give rise, in a deterministic fashion, to collective political subjects - that the way in which various relationships will be understood and which become prioritised over others and made politically salient ultimately depends upon the free choices of those individual subjects political leaders work to convince. But it is also true that one of the key things political leaders typically do, in the course of working out what sort of appeals to make and what sort of political subject to try to build, is to take account of these different pre-existing relationships and potential cleavages in order to find material for piecing together coalitions sufficiently large to defeat the coalitions of their rivals. ${ }^{15}$ What we might loosely call demography, then, or the sociological composition of the electorate in all its complex causal and cultural interrelations, is not destiny. But it does provide the only material from which destiny can be made. One cannot simply render a chain of 'demands' equivalent at will, because demands are not simply freefloating 'signifiers'; they are speech acts made and received by living persons who also stand in other sorts of social relations with each other irreducible to the language of the demands themselves. Actions in the world also have consequences which commonly outrun the meaning of the terms they employ and indeed the intentions of the actors. Laclau's theory has nothing of substance

14 Of course, all descriptions of social relations exist in language, but that is not the same as saying those relations are nothing but language, since one of the things we do in language is to distinguish language from other things (i.e. notlanguage). In other words, although any given description of an agent or addressee is mediated by language, language itself presupposes the existence of a speaker and listener, in time and space, such that they may also stand in relations (such as physical or causal ones) irreducible to the content of a linguistic exchange. Cf. Laclau and Mouffe: 'Our analysis rejects the distinction between discursive and non-discursive practices' (2001: 107).

15 These have long been major topics in empirical literatures. See for instance Kriesi et al. (2012). 
to say about any of these relationships or causal connections, because the only relations it considers are analysed in accordance with the logic of symbols.

This is particularly unfortunate, because studies of populism routinely over-emphasize what populists say, rather than what they actually do, and particularly what sorts of political relationships they create both inside their own 'movements' and with other segments of society. It is true that much of what is distinctive about populism is found in its rhetoric, but part of what is important about the rhetoric is that it is very often designed to focus attention on invective and personality and political theatre, and away from underlying relationships between leaders and followers, or among different segments of its supporting coalition, which often includes some sectors that others would call elites. Certainly, understanding the rhetoric is important to understanding populism, but to understand that rhetoric rightly one needs to see the work it is doing, not only at the rhetorical level, but at the level of political organization, the making possible of certain relationships among different bases and leaders. Of course, the same point can be made about cosmopolitans. The advantage of the democratic realist position defended here, by contrast, is that it brings these further political relationships clearly into view and opens them to consideration and critique on democratic principles.

The third point does not require much explanation. Laclau does not consider the relative sizes of the various social blocs to which one might appeal, which means that, unlike many thinkers in the Marxist tradition he both draws from and criticises, he is unable to form a reasoned view of which groups a political coalition would need to include, in a given society at a given point in time, to have a shot at winning. This is not an ancillary concern, because if one begins from this question, then works back to that of how one might seek to define the identities and interests of specific groups to make possible just that sort of potentially winning coalition, then one arrives at a very different sort of result than if one begins with the general aim of linking every social demand in a chain of equivalences. Consider, for instance, this passage from Gramsci's 1926 Notes on the Southern Question, which Laclau and Mouffe cited in 1985:

'The proletariat can become the leading and dominant class to the extent that it succeeds in creating a system of alliances which allows it to mobilise the majority of the working population against capitalism and the bourgeois State. In Italy, in the real class relations which exist there, this means to the extent that it succeeds in gaining the consent of the broad peasant masses' (Laclau and Mouffe, 2001: 66).

They object that this describes a mere 'class alliance,' praising instead a later passage where Gramsci goes on to write of a new political subject, an artificial 
'collective man' that would unite single wills into one. Of course they are right to stress the political act of construction and to reject any suggestion that class interests are self-evident and determining. ${ }^{16}$ But notice also what they lose Gramsci's clear-eyed assessment of which coalition could win a majority in that historical moment, and therefore the particular task of political mobilisation and cultural construction called for. And yet there is no good reason why all of these considerations cannot be held within a single view.

\section{Democratic Realism and Global Justice?}

So, considered from the point of view of democratic realism, the tension between populism, on the one hand, and cosmopolitanism or global justice, on the other, stems from the fact that they appeal to different segments of the electorate in ways that make it difficult to build a coalition that includes them both. Populism polarizes against elites, but it is also perfectly compatible with polarization against external enemies such as immigrants or foreign competition. Populists have sometimes been able to win on their own, as for instance classically in the case of Juan Perón, but also in recent decades in several Latin American countries, as well as in Eastern Europe and in Turkey. But in richer countries like those of Western Europe and many former British colonies, populists have so far been able to win power only in coalition with significant blocs from more traditional parties. Even in Italy's Lega/Cinque Stelle government of 2018-19, the Lega drew with them a core bloc of their traditional voters committed to their signature flat tax, in addition to those who voted for them to vote against immigration. That government was replaced by one in which the populist Cinque Stelle is supported by the traditional centre-left Democratic Party. In Spain, the left-wing populists Unidos Podemos have entered government only as junior partners in a coalition with the traditional centre-left PSOE. Trump's victory in 2016 and Johnson's in 2019 were possible only because they managed to hold the overwhelming majority of their party's traditional voters even as they convinced new ones to cross over. When Republicans did not manage to hold onto moderate defectors in the 2018 House elections, by contrast, they lost.

What is significant about this is that the search for viable coalition partners, at least in richer countries, appears to create pressures that may tend to favour populists who polarize against external enemies and/or internal minorities rather than domestic elites. The first strategy allows one to continue to court the support of a significant number of business elites and moderates through policies such as tax breaks. The second strategy, by contrast, risks alienating

16 Although I will not argue the textual point here, it is at least possible, moreover, to read even the most deterministic of passages in Gramsci not as simple assertions but as part of a rhetorical project aimed at providing a language that could be used to convince various persons to identify their interests and identities in one way rather than another. 
significant numbers among the liberal, urban middle classes and suburban moderates. Because populist rhetoric involves sharp and moralized polarization, it makes these divisions particularly acute, where another sort of political frame, for instance around rewarding work or a cooperative project of building a better future, might not. And this then makes it difficult when electoral success turns out to require coalition and compromise with traditional, non-populist parties nearer the centre. Accepting such compromise, and 'responsible' action relative to goals of economic growth, can appear as total betrayal, or at least an admission of the failure to overturn the 'rigged' system. Populists who opt for nativism or scapegoating racial minorities, by contrast, do not face the same pressure. They run risks by damaging trade, but as long as the fallout is managed it might be offset by other policies such as tax-breaks designed to keep a sufficient number of business supporters onside. The difference is that nativist populists don't have to demonise a segment of the same people they need to vote for them, since they pick other, easier, targets.

On the other hand, it is no less difficult for cosmopolitans and campaigners for global justice to build coalitions with populists, because their priorities often appear to have little to offer to the concerns of those domestic workingclass constituents to whom populism is especially pitched. This is not to suggest that these groups have only competing interests, only that framing campaigns explicitly around cosmopolitan principles may not be an effective way of building bridges with populists or competing with them for the same pool of voters. Although 'global justice' is more capacious, one may still wonder about the structure of theories and arguments focused on winning over their addressees to acknowledge the reality and urgency of obligations across borders. Other approaches are however imaginable. For instance, a strong defence of labour rights, in both richer and poorer countries, might plausibly hope to win support from both blocs, without first needing to inspire commitment among workingclass constituencies in the richer countries to what is specifically global in the cause of 'global justice.' Something like this appears to have played an important role, for instance, in the recent negotiation of the United States Mexico Canada Agreement. Whatever one thinks of the deal, the point is that a figure like The American Federation of Labor and Congress of Industrial Organizations (A.F.L.C.I.O.) President Richard Trumka could defend that deal (in its final version) on the grounds that it 'means a more level playing field for working people across the continent' (Trumka, 2019). This is an argument about competing (if also partly overlapping) interests rather than one from strictly universalistic premises or a global point of view - the point of the A.F.L-C.I.O.'s successful insistence on a provision whereby unions can trigger investigations of potential 
violations to Mexican workers' rights, Trumka underlined, is that because of it, 'when we're successful, we can stop their product from coming to the United States, it stops at the border' (Shalal and Shepardson, 2019). This is far from cosmopolitanism, but how might thinking in this sort of way, rather than, for instance, in the familiar terms of universal distributive obligations, open new angles for theorizing the politics of global justice?

Democratic realism suggests that if one wishes to pursue ends of global justice, then the first question one would need to ask is 'what sort of coalition would be in a position to take and wield power, where, in order to accomplish this?' This would appear to point first of all to states, not because of any principled argument for state authority or the territorial bounds of distributive duties, but simply because these are the most obvious agents whose actions could bear on the problem and which one might hope to influence through democratic elections. The European Union is also a crucial organization, but its capacity to act depends to a great extent upon the will of the governments of member states, as well as on the larger political climate driven, significantly, by nationallevel political contests. Other intra-state organisations may also play important, if more limited, roles. What democratic realism asks us to do is to step back from familiar philosophical debates over obligations of justice to consider first which actors are in a position to do something about any such obligations. If states remain the most important actors, and many of those states are governed democratically, then it follows that the central question for global justice campaigners should concern what sorts of domestic political coalitions could be in a position to win elections and put into place policies more consistent with global justice.

Those policies might be anything. One might particularly consider, however, efforts to create or strengthen international agreements and institutions, even when those are only regional or otherwise fall far short of global ideals. Even bilateral agreements can create frameworks in which economic relationships that would otherwise be determined entirely de facto or through confrontation among states can be brought into the space of political negotiation. Of course, the content of particular agreements may support inequalities and injustices, but the existence of an agreement and the possibility of subsequently renegotiating it opens a door towards political control at least potentially subject to democratic checks and improvement. The approach I am suggesting allows one sort of framework in which those concerned with justice beyond borders might support and defend existing international agreements and institutions, renegotiating them when appropriate. This does not mean that pulling out of bad agreements would be ruled out, but the aim would be to return to the table whenever a decent agreement became possible. 
In order to make any of this work, however, everything depends upon building domestic political coalitions that can win elections - and this remains true even if one rejects the suggestion above and supposes that most international agreements are worse for global justice than no agreements and ought to be abolished. This means that campaigners for global justice will need to consider the challenge posed by populists - not at the level of principles, but in terms of competition for the votes needed to build electoral majorities. When domestic working-class constituencies and others who may see themselves in economic competition with persons abroad are needed as part of any viable coalition, it becomes necessary for global justice campaigners to address their concerns directly. This does not mean choosing one side or the other - my point is rather that all the serious questions in democratic politics involve coalitions. But in certain cases it might involve, for instance, some controls on trade that might make it possible to sustain threatened domestic industries, in exchange for less draconian immigration policies. Or any of a number of redistributive measures, including those targeting certain industries or regions, might be traded off against freer trade. This is the sort of thinking that proponents of global justice should be engaged in.

Even philosophers concerned solely with ethical justification need to begin from this sort of analysis, because what needs to be justified is not only an abstract obligation but a particular political choice that entails working together with other persons. Political actions are only accomplished collectively, and in joining up with certain of one's fellows to advance shared ends and to oppose the designs of others, one creates new political relationships that must themselves be open to criticism on democratic grounds. Imagine, for instance, that one accepts a version of Joseph Carens' (2013) notable argument for open borders. But then consider how the argument might figure in democratic politics. It matters practically when a majority does not already support that position, and one hopes to argue some fellow citizens to change their minds. But in making this sort of argument, one must ask those fellows not only to accept the claim concerning justice - one also implicitly asks them to accept that this specific claim is sufficient for political judgment, that the other sorts of political relationships that will be brought into effect by any movement in the proposed direction are irrelevant to the praiseworthiness of the outcome. I am not referring here to the sort of direct counter-claims that might be levelled by opponents of unlimited immigration on behalf of competing principles, interests or perceived interests, which Carens answers in at length in chapter twelve of his book. I am referring to other relationships that do not appear anywhere in the book - the political relationships that keep certain leaders, drawing support from certain coalitions, in power. 
Insisting on open borders without regard to the political coalitions that might be expected to support or oppose open borders hides from view an entire range of political phenomena and ignores the problem of who is in control of governments and on what terms. But clearly these latter questions are of great importance. And so, it might well be that persons who do not have a defensible objection against immigrants might nevertheless have one to make against the composition of a governing political coalition supported by calls for open borders. It might be, for instance, that only a coalition dominated by the highly educated would support such a policy, and so one would be asking people, in effect, to support that sort of coalition rather than a different coalition in which people with a wider range of educational backgrounds also had a seat at the policy-making table and a chance to represent their legitimate interests and concerns - including concerns on issues quite apart from immigration.

This might, of course, prove self-defeating, politically, if only the second coalition were broad enough to have a shot at winning. But it could also be attacked as an ethical mistake, because it would amount to arbitrarily privileging a focus on certain social and political relations as the decisive objects of considerations of justice (or democracy), whilst ignoring others no less deserving of consideration. Notice that this is not to say that if some people object to immigration, that very fact makes their view defensible. Even if their view is wholly indefensible, however, it could still be the case that the political relationships created by ignoring them are themselves also objectionable in their own right. What I am arguing is that normative arguments concerning democratic politics need to track two distinct levels of relationships at the same time. One level comprises the relationships at stake in the policy. The second level is that of the relationships internal to the political agent, understood as a governing coalition, which would be in a position to implement and sustain the policy, as well as relationships of that ruling coalition to other members of the society. If one focuses only on the former, then one misses crucial relations of justice and injustice and one's opponents will always be able to point to this and use it as a way of charging one with hypocrisy or selective myopia. Good arguments over justice in democratic politics need to consider both levels, and to look for ways of reducing the conflict between them. This, however, would require a way of thinking that begins from the question of political coalitions, as I have been arguing.

Perhaps the force of my worry here will be clearer if one considers an analogy. One might suppose that a certain social policy is justified - say, for instance, some relatively egalitarian distribution of income (within a state). Now consider four cases, two authoritarian governments and two freely-elected, democratic 
ones. Clearly an authoritarian government with bad distributional policy is bad. But would we want to say that an authoritarian government with the right policy is our normative ideal? Or do we want to say that both this case, and that of a democratic government with bad policy, leave something important to be desired? Wouldn't we obviously be right to insist that we should really aim for the fourth case, one in which both the policy, and the political relations internal to the process behind the policy, are defensible in their own right? Indeed isn't this, for many of us, part of the point of supporting democratic governments instead of hoping for enlightened absolutisms? Here, I'm not concerned with whether to prioritise the political or policy relations if one has to choose - my point is simply that neither is sufficient to be criterial on its own. This seems to me to be an essential point about democratic politics, or indeed any sort of politics, and something that distinguishes it sharply from the sort of individual moral judgment that one might perhaps take oneself be concerned with in philosophical ethics. A great deal of ink has been spilled in recent years on varieties of realism, but very little of it concerns the sorts of issues democratic realism puts front and centre - the complex political relationships internal to the collective agents without whom nothing happens in politics. ${ }^{17}$

\section{Conclusion}

I have argued that populism, cosmopolitanism, and calls for global justice are all best understood, not as theoretical positions but as appeals to different segments of democratic electorates in the hopes of assembling winning political coalitions. When viewed this way, one can understand the sorts of challenges each faces, and also where and how they come into conflict, in a distinctive sort of way. This view is democratic in that it concerns political competition in democracies, and it is realist in the sense that it seeks to evaluate in the first instance not the content of competing political claims but rather the nature of the relationships among different components of the coalitions they work to mobilise in the pursuit of power. This approach allows one to ask two sorts of questions. The first sort is empirical, concerning the makeup of given electorates and potentials for mobilizing various cleavages sometimes in new and unexpected ways. The second is normative, concerning the defensibility of those relationships internal and external to the political coalitions required to govern and advance a given programme. This amounts to a very distinctive sort of realism, one that does not reduce to accommodating to existing reality, although it does demand attention to and engagement with that reality. By

17 Even when a work like Wendt (2016) makes a case for compromise and modus vivendi, it does so with a general moral argument for compromise as such; this has nothing to do with the sort of particular judgments about which compromises to make and which not to, in order to build winning coalitions in pursuit of certain ends, which democratic realism brings to the fore. 
focusing attention on the issues raised by the need for political coalitions to govern in democracies, it hopes to offer a new perspective on familiar debates concerning populism, cosmopolitanism, and global justice.

\footnotetext{
Christopher Meckstroth

University Senior Lecturer in Political Thought

Faculty of History

University of Cambridge

email:cm753@cam.ac.uk

the global justicenetuork
} 


\section{Bibliography}

Bodin J (1576) Les Six Livres de la République. Paris: Jacques Du Puys.

Bourke R and Skinner Q (eds) (2016) Popular Sovereignty in Historical Perspective.

Cambridge: Cambridge University Press.

Brettschneider C (2007) Democratic Rights: The Substance of Self-Government. Princeton, NJ:

Princeton University Press.

Caney S (2005) Justice Beyond Borders: A Global Political Theory. Oxford: Oxford

University Press.

Canovan M (1999) Trust the People! Populism and the Two Faces of Democracy.

Political Studies 47: 2-16.

Canovan M (2005) The People. Cambridge: Polity Press.

Carens J (2103) The Ethics of Immigration. Oxford: Oxford University Press.

Cohen JL (2006) Sovereign equality vs. imperial right: The battle over the new world order. Constellations 13/4: 485-505.

Errejón I and Mouffe C (2016) Podemos: In the Name of the People. London: Lawrence and Wishart.

Frank J (2010) Constituent Moments: Enacting the People in Postrevolutionary America. Durham, NC: Duke University Press.

Galston WA (2010) Realism in political theory. European Journal of Political Theory 9/4: 385-411.

Gerbaudo P (2017) The Mask and the Flag: Populism, Citizenism and Global Protest. London: Hurst and Co.

Geuss R (2008) Philosophy and Real Politics. Princeton, NJ: Princeton University Press.

Goodwyn L (1976) Democratic Promise: The Populist Movement in America. Oxford: Oxford University Press.

Gourevitch A (2019) Leave the EU Already. Jacobin. Available at: https://www.jacobinmag. com/2019/01/brexit-european-union-populism-democracy (accessed 28 October 2020).

Habermas J (1996) Between Facts and Norms: Contributions to a Discourse Theory of Law and Democracy. Cambridge, MA: MIT Press.

Hall E (2017) How to do realistic political theory (and why you might want to). European Journal of Political Theory 16/3: 283-303.

Hall E and Sleat M (2017) Ethics, morality and the case for realist political theory. Critical Review of International Social and Political Philosophy 20/3: 278-295.

Ingram J (2017) Populism and Cosmopolitanism. In: Rovira Kaltwasser C, Taggart P, Ochoa Espejo P and Ostiguy P (eds) The Oxford Handbook of Populism. Oxford: Oxford University Press: 645-66o. 
Kazin M (2017) The Populist Persuasion: An American History. Revised ed. Ithaca, NY: Cornell University Press.

Kriesi H, Grande E, Dolezal M, Helbling M, Höglinger D, Hutter S and Wüest B (2012) Political Conflict in Western Europe. Cambridge: Cambridge University Press.

Laclau E (2005) On Populist Reason. London: Verso.

Laclau E and Mouffe C (2001) Hegemony and Socialist Strategy: Towards a Radical Democratic Politics. London: Verso.

Mansbridge J and Macedo S (2019) Populism and Democratic Theory. Annual Review of law and Social Science 15: 59-77.

McKean B (2016) Toward an Inclusive Populism? On the Role of Race and Difference in Laclau's Politics. Political Theory 44/6: 797-820.

McQueen A (2017) Political realism and the realist 'Tradition.' Critical Review of International Social and Political Philosophy 20/3: 296-313.

Meckstroth (2015) The Struggle for Democracy: Paradoxes of Progress and the Politics of Change. Oxford: Oxford University Press.

Miller D (2007) National Responsibility and Global Justice. Oxford: Oxford University Press.

Morgan E (1988) Inventing the People: The Rise of Popular Sovereignty in England and America. New York: Norton.

Mudde C (2013) Three decades of populist radical right parties in Western Europe: So what? European Journal of Political Research 52/1: 1-19.

Mudde C and Rovira Kaltwasser C (2017) Populism: A Very Short Introduction. Oxford: Oxford University Press.

Mueller JW (2016) What is Populism? Philadelphia: University of Pennsylvania Press.

Orbán V (2018) Prime Minister Viktor Orbán’s speech at the 29th Bálványos Summer Open University and Student Camp, 28 July 2018. Miniszterelnok.hu. Available at: http://www. miniszterelnok.hu/prime-minister-viktor-orbans-speech-at-the-29th-balvanyos-summer-openuniversity-and-student-camp/ (accessed 28 October 2020).

Pogge T (2002) World Poverty and Human Rights: Cosmopolitan Responsibilities and Reforms. Cambridge: Polity Press.

Prinz J and Rossi E (2017) Political realism as ideology critique. Critical Review of International Social and Political Philosophy 20/3: 334-348.

Risse M (2012) On Global Justice. Princeton, NJ: Princeton University Press.

Rosanvallon P (1998) Le Peuple Introuvable: Histoire de la représentation démocratique en France. Paris: Gallimard.

Rossi E (2019) Being realistic and demanding the impossible. Constellations 26/4: 638-652.

Rossi E and Sleat M (2014) Realism in normative political theory. Philosophy Compass, 9/10: 689-701. 
Rovira Kaltwasser C, Taggart P, Ochoa Espejo P and Ostiguy P (eds) (2017) The Oxford Handbook of Populism. Oxford: Oxford University Press.

Sagar P (2014) From scepticism to liberalism? Bernard Williams, the foundations of liberalism, and political realism. Political Studies 64/2: 368-384.

Sagar R and Sabl A (eds) (2018) Realism in Political Theory. London: Routledge.

Sangiovanni A (2008) Justice and the priority of politics to morality. Journal of Political Philosophy 16/2: 137-164.

Shalal A and Shepardson D (2019) AFL-CIO's Trumka says USMCA is first step to undoing evils of NAFTA. Reuters. Available at: https://uk.reuters.com/article/us-usa-trade-usmca-trumka/ afl-cios-trumka-says-usmca-is-first-step-to-undoing-evils-of-nafta-idUKKBN1YOo4Q (accessed 28 October 2020).

Sleat M (2013) Liberal Realism: A Realist Theory of Liberal Politics. Manchester: Manchester University Press.

Sleat M (ed) (2018) Politics Recovered: Realist Thought in Theory and Practice. New York: Columbia University Press.

Stedman Jones G (1983) Languages of Class: Studies in Working Class History, 1832-1982. Cambridge: Cambridge University Press.

Trumka R (2019) USMCA is a huge win for working people. CNN. Available at: https://edition. cnn.com/2019/12/20/opinions/usmca-huge-win-labor-rights-trumka/index.html (accessed 28 October 2020).

Urbinati N (2014) Democracy Disfigured: Opinion, Truth, and the People. Cambridge, MA: Cambridge University Press.

Waldron J (2013) Political political theory: An inaugural lecture. Journal of Political Philosophy 21/1: $1-23$.

Wendt F (2016) Compromise, Peace and Public Justification: Political Morality Beyond Justice. London: Palgrave MacMillan.

Williams B (2005) Realism and Moralism in Political Theory. In: Williams B In The Beginning Was the Deed: Realism and Moralism in Political Argument. Princeton, NJ: Princeton University Press: 1-17. 